Article

\title{
Performance and Biomass Characteristics of SBRs Treating High-Salinity Wastewater at Presence of Anionic Surfactants
}

\author{
Huiru $\mathrm{Li}^{1}$, Shaohua $\mathrm{Wu}^{1,2}$ and Chunping Yang ${ }^{1,2,3, * \mathbb{C}}$ \\ 1 College of Environmental Science and Engineering, Hunan University and Key Laboratory of Environmental \\ Biology and Pollution Control (Hunan University), Ministry of Education, Changsha, Hunan 410082, China; \\ lihuiru@hnu.edu.cn (H.L.); wushaohua@hnu.edu.cn (S.W.) \\ 2 Guangdong Provincial Key Laboratory of Petrochemical Pollution Processes and Control, School of \\ Environmental Science and Engineering, Guangdong University of Petrochemical Technology, Maoming, \\ Guangdong 525000, China \\ 3 Hunan Provincial Environmental Protection Engineering Center for Organic Pollution Control of Urban \\ Water and Wastewater, Changsha, Hunan 410001, China \\ * Correspondence: yangc@hnu.edu.cn
}

Received: 1 March 2020; Accepted: 8 April 2020; Published: 14 April 2020

\begin{abstract}
Sodium dodecylbenzene sulfonate (SDBS) and sodium dodecyl sulfate (SDS), as two anionic surfactants, have diffused into environments such as surface water and ground water due to extensive and improper use. The effects on the removal performance and microbial community of sequencing batch reactors (SBRs) need to be investigated in the treatment of saline wastewater containing $20 \mathrm{~g} / \mathrm{L}$ $\mathrm{NaCl}$. The presence of SDS and SDBS could decrease the removal efficiencies of ammonia nitrogen and total phosphorus, and the effect of SDS was more significant. The effect of surfactants on the removal mainly occurred during the aeration phase. Adding SDS and SDBS can reduce the content of extracellular polymeric substances (EPS). In addition, SDS and SDBS also can reduce the inhibition of high salinity on sludge activity. A total of $16 \mathrm{~s}$ of rRNA sequencing analysis showed that the addition of surfactants reduced the diversity of microbial communities; besides, the relative abundance value of the dominant population Proteobacteria increased from $91.66 \%$ to $97.12 \%$ and $93.48 \%$ when SDS and SDBS were added into the system, respectively.
\end{abstract}

Keywords: saline wastewater; SBR; activated sludge; extracellular polymeric substance; microbial community

\section{Introduction}

Although more than $70 \%$ of Earth's surface is covered by water, freshwater that can be directly used for human activities is less than $1 \%$ of global water volume [1]. Due to the increasingly severe situations of freshwater shortage, the direct application of seawater to industrial production and daily life has become a trend. In some industries, such as the printing and dyeing industry, the presence of salt can promote dyeing and improve the quality of textiles. The direct utilization of seawater in the printing and dyeing industry can greatly reduce production costs. The increase of such industries has reduced the loss of fresh water and produced a large amount of saline wastewater. As a result, the discharge of saline wastewater from chemical plants, smelters, and oil production plants has significantly increased in the last decade [2]. If the saline wastewater is discharged directly into the environment without proper treatment, it will detrimentally affect the soil, surface water, and groundwater [3]. Wastewater treatment plants [4] are important systems to prevent the spread of harmful materials to the environment $[5,6]$. There are many ways to remove pollutants from 
wastewater [7-9]. Physicochemical and biological methods are widely used to treat high-salinity wastewater [10]. The former mainly includes evaporation, electrolysis, coagulation and sedimentation, and membrane separation technology [11]. Unfortunately, the high-cost and potential secondary pollution associated with these methods hampered their applications. Taking environmental protection and economic cost into account, the biological treatment of wastewater has gained popularity owing to the advantages of no secondary pollution $[12,13]$. On the other hand, the biological treatment of saline wastewater is facing enormous challenges [2]. It was reported that high salinity had an adverse impact on the microorganisms in the wastewater treatment systems [14]. Case in point, when salinity increases, microbial metabolism is inhibited and the removal efficiencies of total phosphorus (TP) and ammonia nitrogen $\left(\mathrm{NH}_{4}{ }^{+}-\mathrm{N}\right)$ by activated sludge decreases $[15,16]$.

Among the various methods for treating high-salinity wastewater, the biological treatment process has been paid more and more attention due to its low cost and environmental friendliness [17]. To date, sequencing batch reactors (SBRs) have been one of the most widely used biological processes in the wastewater treatment plants. Chen et al. [18] reported that the removal performance of activated sludge in SBRs was significantly inhibited as the salinity was as high as $20 \mathrm{~g} / \mathrm{L}$.

Direct seawater utilization wastewater, such as printing and dyeing wastewater, not only contains high salt content, but also some surfactants. Salt can increase the interfacial activity of surfactants in solution [19]. Previous studies have shown that the presence of salt can enhance the adsorption of surfactants, sodium dodecyl sulfate (SDS), and Sodium dodecylbenzene sulfonate (SDBS) at low concentrations [20]. SDS and SDBS are two commonly used anionic surfactants. SDS has excellent foaming properties. SDBS has good emulsifying properties. They have the characteristics of being low cost and playing an important role in industrial production and daily life. They can easily enter the environment through industrial wastewater and domestic sewage [21,22] and may contribute to occurrence and potential environmental risk [23]. SDS and SDBS have an inhibitory effect on the anaerobic ammonia oxidation of microorganisms [24]. It would be positive to indicate the main consequences of the effect of SDBS regarding the increased solubility of proteins and carbohydrates over the activated sludge reaction. When the dosage of SDBS is $0.02 \mathrm{~g} / \mathrm{g}$ dry sludge, the activity of amylase and proteinase is the best [25]. Moreover, the interaction between salt and surfactant can affect the interfacial tension of the surfactant [26], thus affecting the sludge activity. However, the role of surfactant on the activated sludge system is still unclear, especially under the high salt conditions.

In this paper, the effects of surfactants on the treatment of high-salt wastewater by SBRs were systematically studied, and the nitrogen and phosphorus removal effects of SBRs in the treatment of high-salt wastewater in the presence of surfactants were investigated. The effects of surfactants on the physicochemical properties and microorganisms of activated sludge were analyzed. Through the changes of various parameters, the interaction between salt, surfactant, and microbial flora in activated sludge is analyzed and confirmed. The results show that the presence of surfactant (SDS and SDBS) inhibits the removal efficiencies of nitrogen and phosphorus and promotes the selection of microbial dominant bacteria, which can provide a theoretical basis for the deep understanding of the interactions among high salt, surfactant, and activated sludge.

\section{Materials and Methods}

\subsection{Water Sample Configuration}

The activated sludge used in SBRs in this experiment was taken from Kaifu Sewage Treatment Plant in Changsha City, Hunan province, China. The formula for the synthetic wastewater used in SBRs is as follows: $94.39 \mathrm{mg} / \mathrm{L}\left(\mathrm{NH}_{4}\right)_{2} \mathrm{SO}_{4}$ as a nitrogen source, $460 \mathrm{mg} / \mathrm{L}$ Glucose as a carbon source, $17.57 \mathrm{mg} / \mathrm{L} \mathrm{KH}_{2} \mathrm{PO}_{4}$ as a phosphorus source, and $0.5 \mathrm{~mL} / \mathrm{L}$ trace element concentrate. The ingredients in $1 \mathrm{~L}$ of concentrate include the following: $1.5 \mathrm{~g} \mathrm{FeCl}_{3} \cdot 6 \mathrm{H}_{2} \mathrm{O}, 0.12 \mathrm{~g} \mathrm{ZnSO}_{4} \cdot 7 \mathrm{H}_{2} \mathrm{O}, 0.15 \mathrm{~g} \mathrm{H}_{3} \mathrm{BO}_{3}$, $0.06 \mathrm{~g} \mathrm{Na}_{2} \mathrm{MoO}_{4} \cdot 2 \mathrm{H}_{2} \mathrm{O}, 0.15 \mathrm{~g} \mathrm{CoCl}_{2} \cdot 6 \mathrm{H}_{2} \mathrm{O}, 0.18 \mathrm{~g} \mathrm{KI}, 0.03 \mathrm{~g} \mathrm{CuSO}_{4} \cdot 5 \mathrm{H}_{2} \mathrm{O}, 10 \mathrm{~g}$ EDTA, and $0.12 \mathrm{~g}$ $\mathrm{MnCl}_{2} \cdot 4 \mathrm{H}_{2} \mathrm{O}[18,27]$. The high salt wastewater is obtained by diluting $20 \mathrm{~g} / \mathrm{L} \mathrm{NaCl}$ with tap water. 
The concentration of surfactants was $0.08 \mathrm{~g} / \mathrm{L}$. The compound comprised to two kinds of synthetic wastewater, one with SDS and another with SDBS, as well as the control with the same formula but without any surfactant.

\subsection{Operation of Reactors}

This study was carried out in three SBRs, and each reactor had an effective volume of $3 \mathrm{~L}$. Three SBRs were all operated with the influent salinity of $20 \mathrm{~g} / \mathrm{L}$. Filler studies were performed in three stable SBRs. SBR1 was the control without the addition of surfactants, while SBR2 and SBR3 were dosed with $0.08 \mathrm{~g} / \mathrm{L}$ SDS and SDBS, respectively. The initial concentrations of mixed liquor suspended solids in SBR 1, SBR 2, and SBR 3 were $4500 \mathrm{mg} / \mathrm{L}$.

There were three operation cycles with the SBRs per day. The flow of each cycle was as follows: $0.05 \mathrm{~h}$ for feeding, $3.5 \mathrm{~h}$ of aeration reaction after $1 \mathrm{~h}$ of standing, $2 \mathrm{~h}$ for stirring, $0.5 \mathrm{~h}$ for settling, $0.05 \mathrm{~h}$ for decanting, and $0.9 \mathrm{~h}$ of idle period. Although the composition of the influent streams was different, the operating conditions of each reactor were the same. The duration of each step in the reaction was regulated by the time controllers. Two peristaltic pumps were used to feed and draw the influent and effluent of SBRs. The temperature of the reactors was controlled by temperature conditioners and the temperature in the reactors were maintained at $25^{\circ} \mathrm{C}$. During the aeration phase, aeration is achieved by an electromagnetic air compressor. During the anoxic phase, the aeration was stopped, a magnetic stirrer was used to stir, and the system was maintained in an anoxic environment.

Analytical methods and $16 \mathrm{~S}$ rRNA sequencing analysis are available in the supporting material. Among them, the 16S rRNA gene amplicon products were sequenced using the HiSeq2500 platform at Illumina. Moreover, the analysis methods of Alpha diversity and beta diversity of microbial community are also included.

\section{Results and Discussion}

Figure $\mathrm{S} 1$ shows the effect of surfactant addition on the removal rate of $\mathrm{NH}_{4}{ }^{+}-\mathrm{N}$ and TP in the SBRs system. Among the three stable SBRs, the surfactants SDS and SDBS were added to SBR2 and SBR3, respectively. After about 35 days, the removal rates of $\mathrm{NH}_{4}{ }^{+}-\mathrm{N}$ and TP in the three SBRs systems reached stability again. Maintain a steady state for a period of time and select a typical operating cycle for more in-depth inspection research.

\subsection{Removal Performance Analysis}

The $\mathrm{N}$ and P removal performance of SBRs is presented in Figure 1a,b. Overall, comparing with the control, the addition of surfactants affected mainly the removal rates of $\mathrm{NH}_{4}{ }^{+}-\mathrm{N}$ and TP [28]. The removal of $\mathrm{NH}_{4}{ }^{+}-\mathrm{N}$ was inhibited in the presence of SDS and SDBS, and the related removal efficiency decreased from $63.41 \%$ to $42.57 \%$ and $59.81 \%$, respectively. Moreover, the concentration profiles of $\mathrm{NO}_{2}{ }^{-}-\mathrm{N}$ and $\mathrm{NO}_{3}{ }^{-}-\mathrm{N}$ within one operational cycle were also monitored. Figure $1 \mathrm{c}, \mathrm{d}$ shows the variation of $\mathrm{NO}_{2}{ }^{-}-\mathrm{N}, \mathrm{NO}_{3}{ }^{-}-\mathrm{N}$ during an operation cycle, respectively. Under high salt conditions, the presence or absence of surfactants has basically the same effect on the content of $\mathrm{NO}_{2}{ }^{-}-\mathrm{N}$ in SBR. Nevertheless, in the system with SDS and SDBS, the nitrate nitrogen content increased significantly during the reaction and nitrification and denitrification enhancement [29]. It was indicated that nitrification and denitrification have a great influence on the denitrification efficiency of the system [30-32]. The comparison of Figure 1a,d showed that that the concentration of $\mathrm{NO}_{3}{ }^{-}-\mathrm{N}$ is the highest, while the removal rate of $\mathrm{NH}_{4}{ }^{+}-\mathrm{N}$ is the lowest, in the presence of SDS. It was found that the activated sludge in SBRs was affected not only by surfactants [23,33], but also by high salinity [20,26,34]. High salinity has a strong inhibition effect on sludge activity [18], but the interaction between surfactant and salt weakens the inhibition of salt on the activated sludge. Figure $1 \mathrm{~b}$ has shown that the effect of the presence of two surfactants on the TP removal rate in the system. Considering the kinetic factors, 
by fitting equations to the experimental data, among the three sets of data, the TP removal rate changes with the time $(t)$ during the operation cycle and satisfies the following formulas:

$$
\begin{aligned}
& r_{(\text {control })}=-40.03715+48.19004 \times t-9.11171 \times t^{2}+0.76962 \times t^{3}-0.02466 \times t^{4} \\
& r_{(S D S)}=-48.49176+67.42909 \times t-23.16313 \times t^{2}+3.65602 \times t^{3}-0.20901 \times t^{4} \\
& r_{(S B D S)}=-22.58669+24.41505 \times t-5.28091 \times t^{2}+0.94579 \times t^{3}-0.06628 \times t^{4}
\end{aligned}
$$

where $r_{(\text {control })}, r_{(S D S)}$ and $r_{(S B D S)}$ are the removal rate of TP in the control system, the SDS-containing system, and the SDBS-containing system, respectively. The quality of the fit polynomial model was expressed by the coefficient of determination $\mathrm{R}^{2}$. It can be seen from Figure $1 \mathrm{~b}$ that the removal rate of TP hardly changed during the standing period, and, when aeration started, the three lines have a good fitting effect. The addition of SDS reduced the removal rate of TP from $55.64 \%$ to $41.34 \%$, while the addition of SDBS only inhibited the removal of TP in the initial stage of the reaction; after a short lag phase, the removal rate of TP rose to $55.06 \%$, the inhibition effect weakened, and, ultimately, TP reverted to the same level as the control. This is probably because the addition of anionic surfactants inhibited the reaction when phosphorus accumulating organisms use oxygen as electron acceptor to remove TP. Additionally, due to the difference in molecular size and stability between SDS and SDBS, the inhibitory effects on SDS and SDBS are different [35]. When the removal efficiencies of $\mathrm{NH}_{4}{ }^{+}-\mathrm{N}$ and TP were stable, the removal performance of nitrogen and phosphorus in the system containing SDS and SDBS were inhibited. From previous studies, the kinetic studies on the removal rates of ammonia nitrogen and TP in the SBRs system are less than nitrate nitrogen and nitrite nitrogen. However, from the comparison of the removal rate, since this experiment is to add surfactant under high salt conditions where the activated sludge can maintain activity, this result is quite impressive [1,18,31]. The reduction in nitrogen and phosphorus removal during the reaction may be due to the effects of salts and surfactants. The pressure of the cells forces the functional proteins on the cell membrane to increase, and the secretion of glycogen and nucleic acids in the cells is reduced [36]. Glycogen contributes to the storage of nitrogen, and its reduction causes the inhibition of nitrification and denitrification, and nitrogen removal efficiency decreases $[37,38]$. Similarly, the reduction in nucleic acid reduces the removal rate of phosphorus [36]. Meanwhile, the increase in Chemical Oxygen Demand (COD) in the three systems (control, SDS-containing system and SDBS-containing system) were $82.32 \mathrm{mg} / \mathrm{L}, 156.45 \mathrm{mg} / \mathrm{L}$, and $195.49 \mathrm{mg} / \mathrm{L}$, respectively. This may be due to the stress of high salinity and surfactants, resulting in the rupture of some cell membranes during the reaction process. The decrease in SS (suspended solids) content in the system during continuous reaction may also due to this. Theoretically, N and P and COD will be converted into nutrients during the operation of the SBR system [39], promoting the growth of microorganisms and the production of organic matter in the activated sludge, and increasing SS [40,41]. However, in the actual reaction, due to the high salt and surfactant stress, some microbial cells ruptured, the SS in the system decreased, and the COD in the effluent increased. 

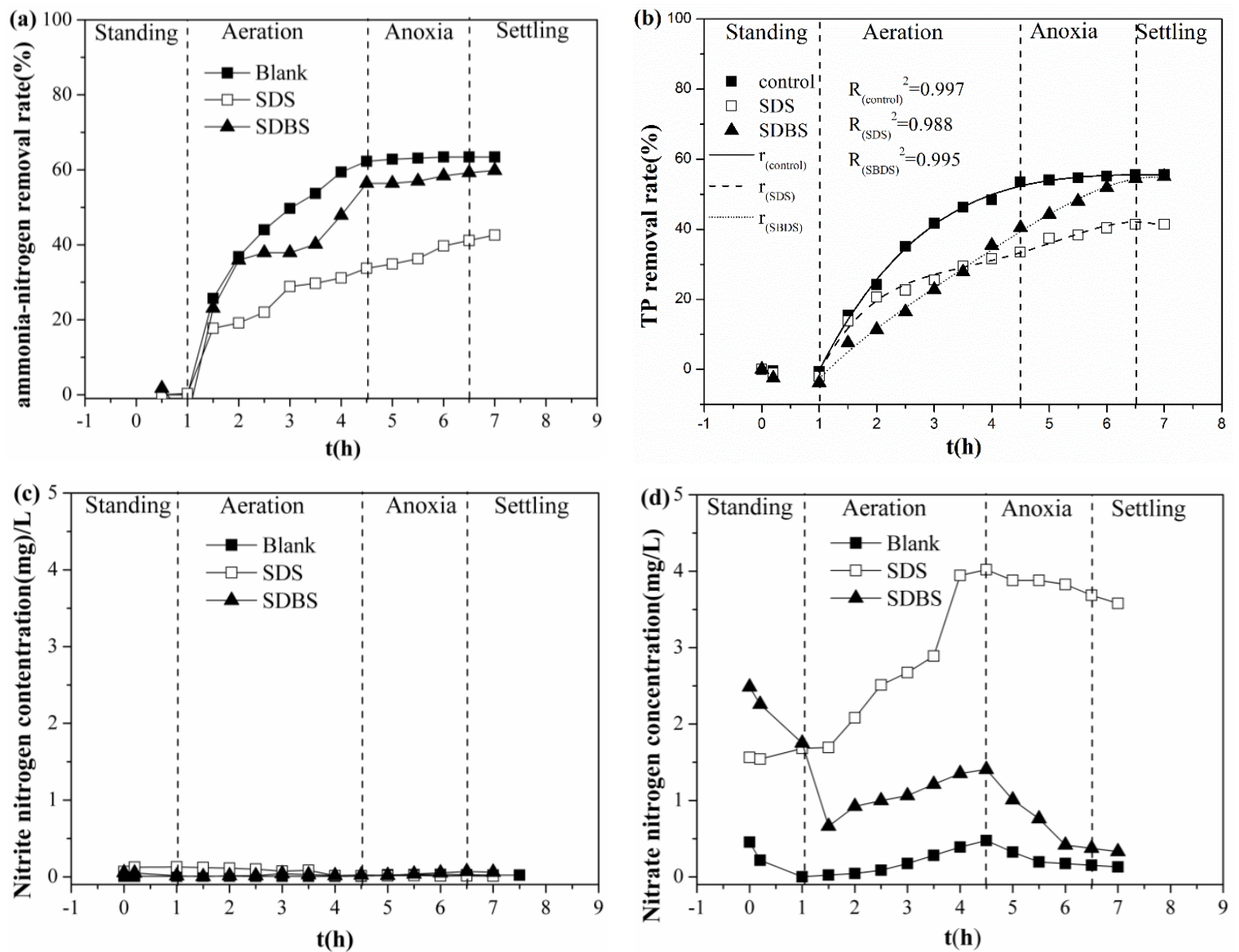

Figure 1. Removal rates of pollutants during an operational cycle: (a) $\mathrm{NH}_{4}^{+}-\mathrm{N}$; (b) $\mathrm{TP}$; (c) $\mathrm{NO}_{2}^{-}-\mathrm{N}$; and (d) $\mathrm{NO}_{3}{ }^{-}-\mathrm{N}$.

\subsection{Activated Sludge Performance Analysis}

The influence of surfactants on the performance of activated sludge is generally manifested in the sedimentation of activated sludge, the variation of extracellular polymer substance (EPS), and microbial enzyme activities. These three characteristics of activated sludge were closely related to each other [42]. For instance, the composition and proportion of EPS have a great influence on microbial enzyme activity and sludge sedimentation. EPS is composed of proteins (PN), polysaccharides (PS), and nucleic acids. Among them, $70 \%-80 \%$ of EPSs are proteins and polysaccharides [43,44]. In addition, EPS can enrich nutrients in the environment and has an important influence on flocculation structure and settling performance of activated sludge [45].

In addition, dehydrogenase is an oxidoreductase that can catalyze substances. It can reflect not only the degradation ability of microorganisms but also the operation effect of the reactor in the process of organic matter removal. Variations of the dehydrogenase activity (DHA) under surfactant stress are shown in Figure 2a. The content of DHA in the system with SDBS is $55.65 \mathrm{mg}$ TF/g TSS/h, similar to the $50.57 \mathrm{mg} \mathrm{TF} / \mathrm{g}$ TSS/h in the control system. The content of DHA in the system with SDS is $226.11 \mathrm{mg}$ $\mathrm{TF} / \mathrm{g} \mathrm{TSS} / \mathrm{h}$, obviously higher than that of the former two, which indicated that the addition of SDBS had little effect on the activity of microbial enzymes. Nevertheless, the activity of microbial enzymes in the SDS-containing system was somehow higher than the control and SDBS-containing system. This is mainly due to the interaction between SDS and salt ions, which reduced the inhibition of high salt on the activity of the microbial enzymes [46]. The variations of EPS contents under surfactant stress were shown in Figure 2b, and the addition of SDS and SDBS could reduce the EPS content of the system from 37.25 to 25.90 and $24.53 \mathrm{mg} / \mathrm{g} \mathrm{SS}$, respectively. The content of PN and the loosely 
bound extracellular polymeric substances (LB-EPS) also decreased, respectively. The content of the tightly bound extracellular polymeric substances (TB-EPS) in the system containing SDBS was almost unchanged, while the content of TB-EPS in the system containing SDS decreased significantly [42].This suggested that the increase in LB-EPS is not conducive to the sedimentation of activated sludge [47]. However, as shown in Figure 2c, the proportion of LB-EPS/EPS in the system containing SDS increased, and the sedimentation of activated sludge increased. The SV30 in the figure refers to the volume percentage of the sludge after the mixed liquid is left in the graduated cylinder for $30 \mathrm{~min}$. A small SV30 value indicates good sludge sedimentation. In the SDBS-containing system, the percentage of LB-EPS/EPS decreased and the sedimentation of activated sludge weakened. There may be two reasons for this result: (1) PS/EPS enhances the ability of PS to protect cells and enhances the sedimentation of activated sludge [42,48]; (2) the interaction between SDS and salt reduces the stress of salt on the system, thus enhancing the sedimentation of activated sludge [46]. SDBS could not reduce the stress of salt on the system, and thereby the activity of enzymes was inhibited. Besides, the interaction between SDBS and salts could not enhance the sedimentation of activated sludge.
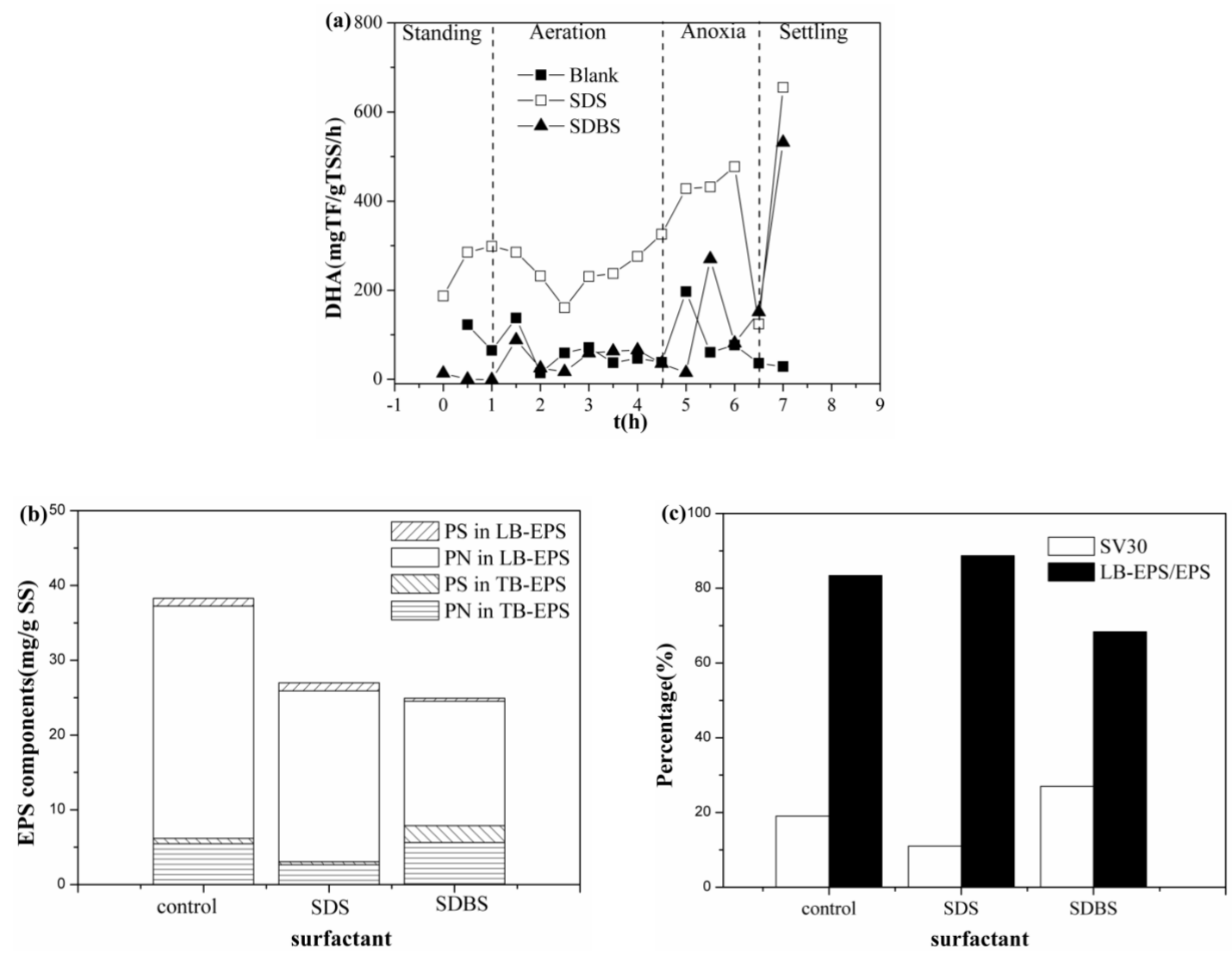

Figure 2. Variation of activated sludge characteristics under different surfactants: (a) dehydrogenase activity (DHA); (b) extracellular polymer substance (EPS); and (c) Sedimentation performance.

\subsection{Microbial Community Structure Analysis}

The alpha diversity index can characterize the complexity of sample species diversity, including population number and the Chao, Shannon, Simpson, and coverage index [18]. The alpha index of three activated sludge samples with the addition of surfactants are presented in Table 1, and the high Good's Coverage indexes of all three samples are 1, which indicated that the sequencing depth of all samples are sufficient [49]. The Chao 1 in the SDS/SDBS-containing systems was lower than that in the control without surfactants, which suggested that the abundance of microbial community decreased due to the addition of surfactants. As the Shannon index is non-linear, MacArthur et al. correctly identified diversity with exp (H_Shannon), and the effective number of species can more intuitively 
compare the richness of different biological flora. As shown in Table 1, the sample with SDBS shows a higher richness and evenness than the control does, while SDS does the opposite. Shannon and Simpson can represent the diversity of microbial communities, the variation of their indices showed that the addition of surfactants SDS and SDBS decreased the diversity of microbial communities in the system [49]. Moreover, the addition of SDS and SDBS reduced the observed species from 250 to 139 and 195, respectively. In general, the addition of surfactant reduced the richness of the biological community, as well as the diversity of the biological community.

Table 1. Alpha index of three activated sludge samples with the addition of surfactants.

\begin{tabular}{ccccccc}
\hline $\begin{array}{c}\text { Sample } \\
\text { Name }\end{array}$ & $\begin{array}{c}\text { Observed } \\
\text { Species }\end{array}$ & Shannon & Simpson & Chao1 & ACE & $\begin{array}{c}\text { Goods' } \\
\text { Coverage }\end{array}$ \\
\hline Control & 250 & 2.882 & 0.700 & 256.000 & 256.270 & 1 \\
SDS & 139 & 2.652 & 0.702 & 145.067 & 147.287 & 1 \\
SDBS & 195 & 3.450 & 0.828 & 206.875 & 205.442 & 1 \\
\hline
\end{tabular}

The Wayne diagram of the microbial community could clearly reflect the effect of two surfactants on SBRs under high salt conditions. Figure S2 has shown that the Shared species among the three samples was 103. The Shared species between every two samples, including the control and SDS, the control and SDBS, and SDS and SDBS, were 120,168, and 112, respectively. This means that under the condition of high salinity, the effects of anionic surfactants on the microbial community diversity of SBRs system were different, and the inhibition of SDBS on the system was less than SDS. This result is in agreement with the fact that the interaction between SDBS and salt cannot reduce the effects of salt stress.

The operational taxonomic unit (OTU) means that the tags clustered at $97 \%$ similarity by UPARSE (version 7.1) [36]. Figure 3a shows the distribution of OTU numbers of the three samples at the seven taxonomic levels of Kingdom, Phylum, Class, Order, Family, Genus, and Species. The OTU numbers at the levels of phylum, genera, and species of dimension were obviously influenced by surfactants. Figure $3 b-d$ shows the microbial population abundance map of activated sludge samples at the phylum, genus, and species level under the effect of surfactant. The addition of SDS and SDBS reduced the number of species classified by the system but increased the number of genera. At the phylum level, the dominant floras of all samples were Proteobacteria, Firmicutes, Bacteroides, Actinomycetes, and Saccharibacteria. Proteobacteria was the most abundant one in the three samples. The relative abundance value of Proteobacteria increased from $91.66 \%$ to $97.12 \%$ and $93.48 \%$ with the addition of SDS and SDBS, respectively. Proteobacteria has strong adaptability under the influence of high salinity and surfactant, and it was reported that the most denitrifying bacteria belonged to Proteobacteria [50-52]. Figure 3d shows that Kluyvera was one of the Proteobacteria that played a major role in this study. The lower the relative abundance of Kluyvera, the lower the nitrogen removal efficiency [53,54]. However, this phenomenon was not observed in this study. This was due to the fact that the removal efficiency of $\mathrm{NH}_{4}{ }^{+}-\mathrm{N}$ is not only affected by effective dominant bacteria but also by the richness and diversity of the microbial community, and the total amount of effective bacteria is the key to nitrogen removal. On the generic level, the dominant genera in the control and SDBS-containing system were Clovera, Candida rubra, and Thiothrix, while the dominant genera of the SDS-containing system were Clovera and Candida rubra. Thiofacillus was beneficial to sulfidation and desulfurization and reduced the impact of SDBS on various indicators of activated sludge in the SBR system. The addition of surfactant reduced the microbial diversity under high salt conditions, but increased the relative abundance of dominant populations. This is one of the reasons why the addition of SDS increased the activity of activated sludge enzymes in the system and increased the content of nitrous nitrogen in the reaction process, but the ability to remove nitrogen and phosphorus decreased. 

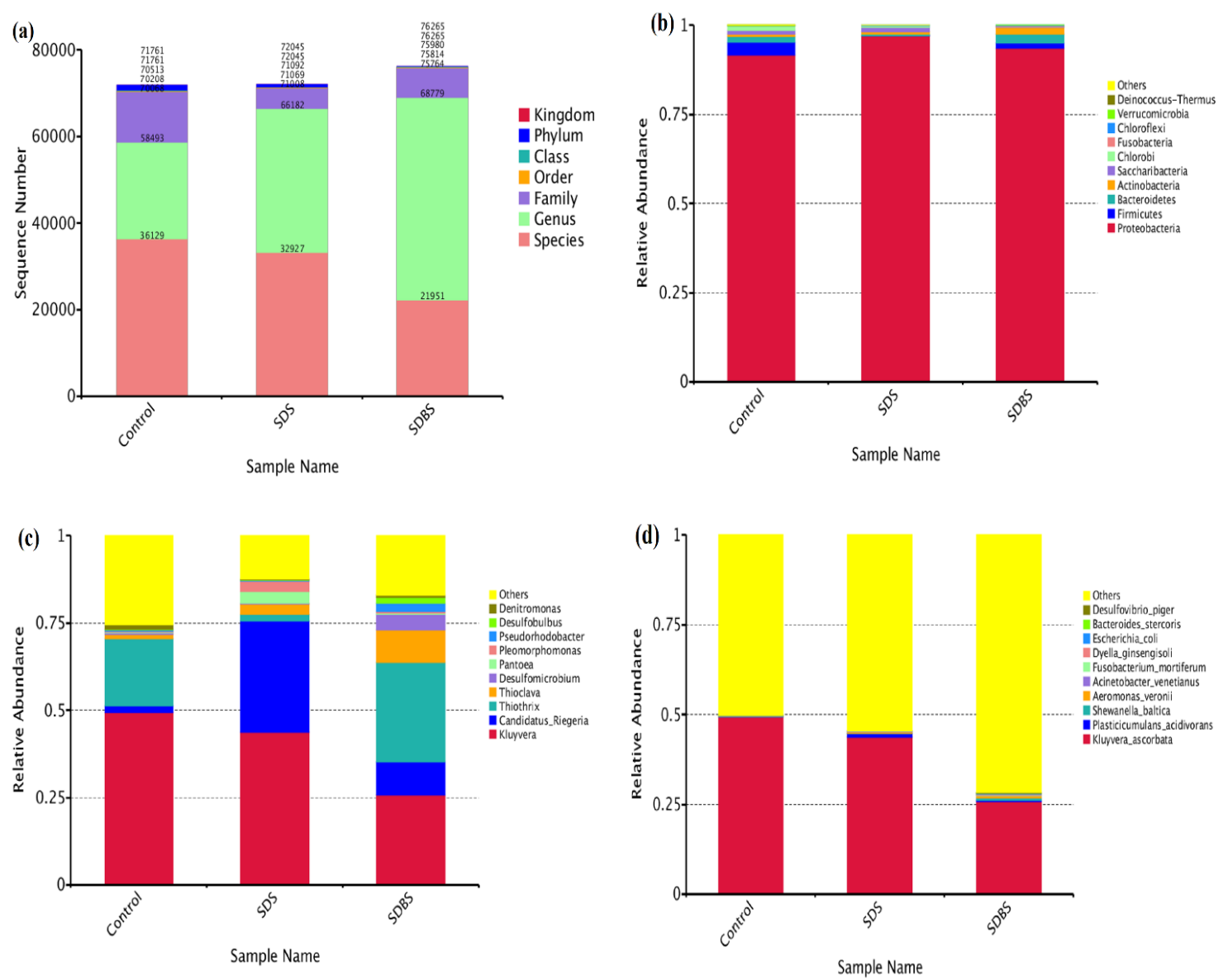

Figure 3. Operational taxonomic unit (OTU) numbers of the 3 samples: (a) at the seven taxonomic levels; (b) at the phylum level; (c) at the genus level; and (d) at the species level.

Figure 4 shows the results of unweighted pair-group method with arithmetic means (UPGMA) analysis on the gate level. The results of UniFrac distance analysis analyzed the diversity of microbial communities by comparing the distance between each two samples and showed that SDS and SDBS have some effects on microbial species. UPGMA analysis based on unweighted UniFrac distance showed that sample SDBS is similar to sample control, which indicates that the difference in microbial population diversity between the SDS-containing system and the control group was greater than that between the SDBS-containing system and the control system. UPGMA analysis based on weighted UniFrac distance showed that the addition of SDS and SDBS not only have effects on microbial species diversity, but also affect the richness of microbial communities. The comparison of relative abundance in phylum level also confirms this conclusion. Therefore, the difference of activated sludge under the influence of surfactant was subjected to the changes in microbial species diversity and microbial community richness. The combination of the inhibitory effect of salt on the sludge activity, the interaction between surfactants and salt, and the effect of surfactants on the microbial community in activated sludge has led to a reduction in the nitrogen and phosphorus removal performance of activated sludge. 


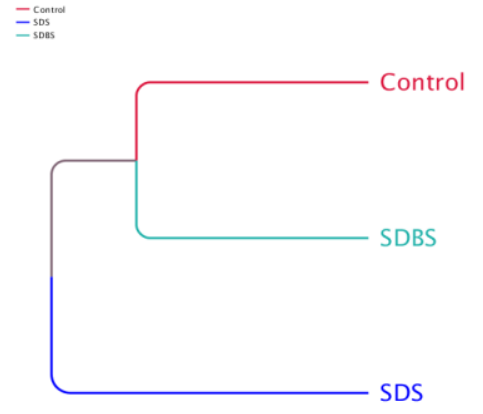

(a)
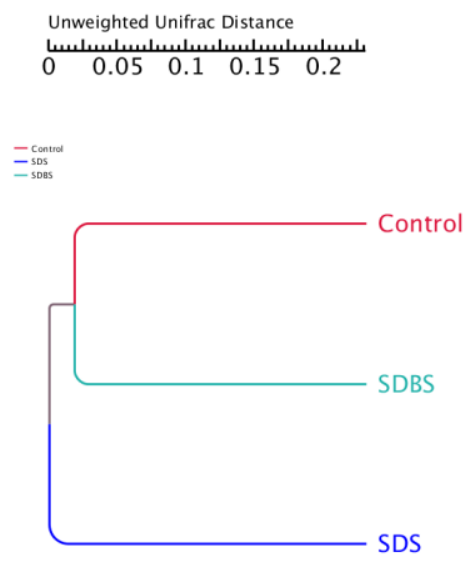

(b)

Weighted Unifrac Distance
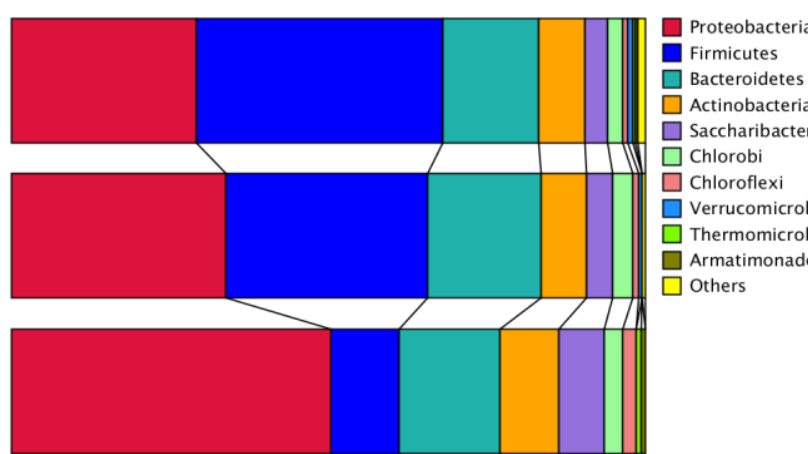

Firmicutes

Bacteroidetes

Actinobacteria

Saccharibacteria

Chlorobi

$\square$ Chloroflexi

Verrucomicrobia

Thermomicrobia

Armatimonadetes $\square$ Others
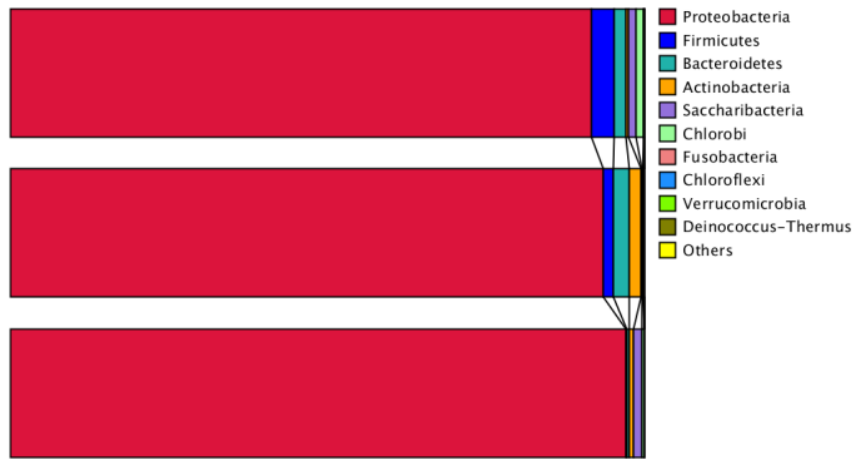

0

$\begin{array}{ccc}0.25 & 0.5 & 0.75 \\ \text { Relative Abundance in Phylum Level }\end{array}$

0.75

\section{1}

Figure 4. UPGMA analysis based on different algorithms at the phylum level of 3 activated sludge samples: (a) the unweighted unifrac distance; (b) the weighted unifrac distance.

\section{Conclusions}

Under high salt conditions, the addition of SDS and SDBS in SBRs can inhibit the removal of nitrogen and phosphorus. The inhibition of SDS is more obvious. Sludge activity was almost affected in the SDBS-containing system, while it increased in the SDS-containing system. The interaction between SDS and salt can reduce salt stress on sludge activity. Besides, the addition of SDS and SDBS reduced the content of the EPS of the system. The content of TB-EPS in the system containing SDBS was almost unchanged, while the content of TB-EPS in the system containing SDS decreased significantly. The 16S rRNA sequencing analysis showed that Proteobacteria was the dominant population in the presence of high salt and surfactant. Moreover, the removal performance of SBRs is affected not only by dominant population but also by microbial community richness and community diversity. Therefore, the reduction in the nitrogen and phosphorus removal performance of activated sludge is the result of several factors acting together.

Supplementary Materials: The following are available online at http:/www.mdpi.com/1660-4601/17/8/2689/s1, Figure S1: the effect of surfactant addition on the removal rate of $\mathrm{NH}_{4}{ }^{+}-\mathrm{N}$ and TP in SBRs system, Figure S2: the Shared species among the three samples was 103.

Author Contributions: Conceptualization, H.L. and C.Y.; formal analysis, H.L., C.Y. and S.W.; investigation, H.L.; methodology, H.L. and C.Y.; validation, H.L., C.Y. and S.W.; funding acquisition, C.Y.; resources, C.Y.; supervision, C.Y. and S.W.; writing—original draft, H.L.; writing—review and editing, H.L., C.Y. and S.W. All authors have read and agreed to the published version of the manuscript.

Funding: This research was funded by the National Natural Science Foundation of China (Grant No.:51978178, 51478172 and 51521006), the Department of Science and Technology of Guangdong Province of China (Contract No.: 2019A1515012044 and 2018S0011), the International S\&T Cooperation Program of China (Contract No.: 
2015DFG92750), and the Department of Science and Technology of Hunan Province of China (Contract No.: 2017JJ2029 and 2017SK2362).

Conflicts of Interest: The authors declare no conflict of interest.

\section{References}

1. Soliman, M.; Eldyasti, A. Long-term dynamic and pseudo-state modeling of complete partial nitrification process at high nitrogen loading rates in a sequential batch reactor (SBR). Bioresour. Technol. 2017, 233, 382-390. [CrossRef] [PubMed]

2. Tang, Y.Q.; Liu, Y.G.; Zhang, T.; Li, J.; Wang, X.H.; Zhang, W.; Zeng, G.M.; Liu, S.B.; Guan, L. Acute Toxicity of Divalent Mercury Ion to Anguilla japonica from Seawater and Freshwater Aquaculture and Its Effects on Tissue Structure. Int. J. Environ. Res. Public Health 2019, 16, 1965. [CrossRef] [PubMed]

3. Lefebvre, O.; Quentin, S.; Torrijos, M.; Godon, J.J.; Delgenès, J.P.; Moletta, R. Impact of increasing $\mathrm{NaCl}$ concentrations on the performance and community composition of two anaerobic reactors. Appl. Microbiol. Biotechnol. 2007, 75, 61-69. [CrossRef] [PubMed]

4. Li, X.; Yang, W.L.; He, H.J.; Wu, S.H.; Zhou, Q.; Yang, C.P.; Zeng, G.M.; Luo, L.; Lou, W. Responses of microalgae Coelastrella sp. to stress of cupric ions in treatment of anaerobically digested swine wastewater. Bioresour. Technol. 2018, 251, 274-279. [CrossRef] [PubMed]

5. Nguyen, L.N.; Oh, S. Impacts of antiseptic cetylpyridinium chloride on microbiome and its removal efficiency in aerobic activated sludge. Int. Biodeterior. Biodegrad. 2019, 137, 23-29. [CrossRef]

6. Saha, S.; Badhe, N.; Pal, S.; Biswas, R.; Nandy, T. Carbon and nutrient-limiting conditions stimulate biodegradation of low concentration of phenol. Biochem. Eng. J. 2017, 126, 40-49. [CrossRef]

7. Schievano, A.; Pepé Sciarria, T.; Vanbroekhoven, K.; De Wever, H.; Puig, S.; Andersen, S.J.; Rabaey, K.; Pant, D. Electro-Fermentation-Merging Electrochemistry with Fermentation in Industrial Applications. Trends Biotechnol. 2016, 34, 866-878. [CrossRef]

8. Phan, H.V.; Hai, F.I.; Zhang, R.; Kang, J.; Price, W.E.; Nghiem, L.D. Bacterial community dynamics in an anoxic-aerobic membrane bioreactor-Impact on nutrient and trace organic contaminant removal. Int. Biodeterior. Biodegrad. 2016, 109, 61-72. [CrossRef]

9. Tadkaew, N.; Hai, F.I.; McDonald, J.A.; Khan, S.J.; Nghiem, L.D. Removal of trace organics by MBR treatment: The role of molecular properties. Water Res. 2011, 45, 2439-2451. [CrossRef]

10. He, H.; Chen, Y.; Li, X.; Cheng, Y.; Yang, C.P.; Zeng, G.M. Influence of salinity on microorganisms in activated sludge processes: A review. Int. Biodeterior. Biodegrad. 2017, 119, 520-527. [CrossRef]

11. Salmanikhas, N.; Tizghadam, M. Rashidi Mehrabadi A: Treatment of saline municipal wastewater using hybrid growth system. J. Biol. Eng. 2016, 10, 9. [CrossRef] [PubMed]

12. Ahmadi, M.; Jorfi, S.; Kujlu, R.; Ghafari, S. Darvishi Cheshmeh Soltani R, Jaafarzadeh Haghighifard N: A novel salt-tolerant bacterial consortium for biodegradation of saline and recalcitrant petrochemical wastewater. $J$. Environ. Manag. 2017, 191, 198-208. [CrossRef] [PubMed]

13. Lefebvre, O.; Moletta, R. Treatment of organic pollution in industrial saline wastewater: A literature review. Water Res. 2006, 40, 3671-3682. [CrossRef] [PubMed]

14. Hong, J.; Li, W.; Lin, B.; Zhan, M.; Liu, C.; Chen, B.Y. Deciphering the effect of salinity on the performance of submerged membrane bioreactor for aquaculture of bacterial community. Desalination 2013, 316, 23-30. [CrossRef]

15. Bassin, J.P.; Dezotti, M.; Sant'Anna, G.L. Nitrification of industrial and domestic saline wastewaters in moving bed biofilm reactor and sequencing batch reactor. J. Hazard. Mater. 2011, 185, 242-248. [CrossRef]

16. Yan, Z.; He, H.J.; Yang, C.P.; Zeng, G.M.; Luo, L.; Jiao, P.; Li, H.R.; Lu, L. Biodegradation of 3,5-dimethyl-2,4-dichlorophenol in saline wastewater by newly isolated Penicillium sp. yz11-22N2. J. Environ. Sci. 2017, 57, 211-220. [CrossRef]

17. Corsino, S.F.; Campo, R.; Di Bella, G.; Torregrossa, M.; Viviani, G. Cultivation of granular sludge with hypersaline oily wastewater. Int. Biodeterior. Biodegrad. 2015, 105, 192-202. [CrossRef]

18. Chen, Y.J.; He, H.J.; Liu, H.Y.; Li, H.R.; Zeng, G.M.; Xia, X.; Yang, C.P. Effect of salinity on removal performance and activated sludge characteristics in sequencing batch reactors. Bioresour. Technol. 2018, 249, 890-899. [CrossRef] 
19. Hu, G.X.; Yang, H.; Hou, Q.F.; Guo, D.H.; Chen, G.; Liu, F.H.; Chen, T.; Shi, X.F.; Su, Y.; Wang, J.B. A pH and salt dually responsive emulsion in the presence of amphiphilic macromolecules. Soft Matter 2018, 14, 405-410. [CrossRef]

20. Kumar, M.K.; Ghosh, P. Coalescence of Air Bubbles in Aqueous Solutions of Ionic Surfactants in Presence of Inorganic Salt. Chem. Eng. Res. Des. 2006, 84, 703-710. [CrossRef]

21. Chen, Y.; Wang, L.; Dai, F.; Tao, M.; Li, X.; Tan, Z. Biostimulants application for bacterial metabolic activity promotion and sodium dodecyl sulfate degradation under copper stress. Chemosphere 2019, 226, 736-743. [CrossRef] [PubMed]

22. Abboud, M.M.; Khleifat, K.M.; Batarseh, M.; Tarawneh, K.A.; Al-Mustafa, A.; Al-Madadhah, M. Different optimization conditions required for enhancing the biodegradation of linear alkylbenzosulfonate and sodium dodecyl sulfate surfactants by novel consortium of Acinetobacter calcoaceticus and Pantoea agglomerans. Enzym. Microb. Technol. 2007, 41, 432-439. [CrossRef]

23. Freeling, F.; Alygizakis, N.A.; von der Ohe, P.C.; Slobodnik, J.; Oswald, P.; Aalizadeh, R.; Cirka, L.; Thomaidis, N.S.; Scheurer, M. Occurrence and potential environmental risk of surfactants and their transformation products discharged by wastewater treatment plants. Sci. Total Environ. 2019, 681, 475-487. [CrossRef] [PubMed]

24. Qiao, S.; Zheng, N.; Tian, T.; Yu, C.; Zhou, J. Effects of short-term exposure to linear anionic surfactants (SDBS, SLS and SDS) on anammox biomass activity. RSC Adv. 2016, 6, 53004-53011. [CrossRef]

25. Yang, Q.; Jing, X.L.; Luo, K.; Yi, J.; Zhong, Q.; Li, X.M.; Liu, Y.; Zeng, G.M. Hydrolase activity during microaerobic thermophilic digestion of sludge affected by sodium dodecylbenzene sulfonate (SDBS). Environ. Eng. Manag. J. 2016, 15, 367-373. [CrossRef]

26. Li, H.R.; Li, Z.Q.; Song, X.W.; Li, C.B.; Guo, L.L.; Zhang, L.; Zhang, L.; Zhao, S. Effect of Organic Alkalis on Interfacial Tensions of Surfactant/Polymer Solutions against Hydrocarbons. Energy Fuels 2015, 29, 459-466. [CrossRef]

27. Wang, D.B.; Li, X.M.; Yang, Q.; Zeng, G.M.; Liao, D.X.; Zhang, J. Biological phosphorus removal in sequencing batch reactor with single-stage oxic process. Bioresour. Technol. 2008, 99, 5466-5473. [CrossRef]

28. Li, X.; Yang, C.P.; Zeng, G.M.; Wu, S.H.; Lin, Y.; Zhou, Q.; Lou, W.; Du, C.; Nie, L.J.; Zhong, Y.Y. Nutrient removal from swine wastewater with growing microalgae at various zinc concentrations. Algal Res. 2020, 46, 101804. [CrossRef]

29. Chen, Y.; Cheng, J.J.; Creamer, KS. Inhibition of anaerobic digestion process: A review. Bioresour. Technol. 2008, 99, 4044-4064. [CrossRef]

30. Li, C.; Liu, S.; Ma, T.; Zheng, M.; Ni, J. Simultaneous nitrification, denitrification and phosphorus removal in a sequencing batch reactor (SBR) under low temperature. Chemosphere 2019, 229, 132-141. [CrossRef]

31. Capodici, M.; Corsino, S.F.; Torregrossa, M.; Viviani, G. Shortcut nitrification-denitrification by means of autochthonous halophilic biomass in an SBR treating fish-canning wastewater. J. Environ. Manag. 2018, 208, 142-148. [CrossRef] [PubMed]

32. Li, N.; Wang, P.; Liu, Q.; Cao, H. Microwave enhanced chemical reduction process for nitrite-containing wastewater treatment using sulfaminic acid. J. Environ. Sci. 2010, 22, 56-61. [CrossRef]

33. Cheng, Y.; He, H.J.; Yang, C.P.; Yan, Z.; Zeng, G.M.; Qian, H. Effects of anionic surfactant on n-hexane removal in biofilters. Chemosphere 2016, 150, 248-253. [CrossRef] [PubMed]

34. Lv, K.; Huang, P.; Liang, Y.; Lian, P.; Yan, H.; Jia, H. The great improvement of the surfactant interfacial activity via the intermolecular interaction with the additional appropriate salt. Colloids Surf. A Physicochem. Eng. Asp. 2018, 554, 142-148. [CrossRef]

35. Semerci, N.; Hasılcı, N.B. Fate of carbon, nitrogen and phosphorus removal in a post-anoxic system treating low strength wastewater. Int. Biodeterior. Biodegrad. 2016, 108, 166-174. [CrossRef]

36. Zhu, Y.; Zhang, J.; Ningyuan, Z.; Jun, T.; Liu, J.; Sun, P.; Wong, P.K. Phosphorus and Cu ${ }^{2+}$ removal by periphytic biofilm stimulated by upconversion phosphors doped with $\operatorname{Pr}^{3+}-\mathrm{Li}^{+}$. Bioresour. Technol. 2017, 248, 68-74. [CrossRef] [PubMed]

37. Yang, G.; Wang, J. Changes in microbial community structure during dark fermentative hydrogen production. Int. J. Hydrog. Energy 2019, 44, 25542-25550. [CrossRef]

38. Amorim, C.L.; Maia, A.S.; Mesquita, R.B.; Rangel, A.O.; van Loosdrecht, M.C.; Tiritan, M.E.; Castro, P.M. Performance of aerobic granular sludge in a sequencing batch bioreactor exposed to ofloxacin, norfloxacin and ciprofloxacin. Water Res. 2014, 50, 101-113. [CrossRef] 
39. Yusoff, N.; Ong, S.A.; Ho, L.N.; Wong, Y.S.; Saad, F.N.M.; Khalik, W.; Lee, S.L. Performance of the hybrid growth sequencing batch reactor (HG-SBR) for biodegradation of phenol under various toxicity conditions. J. Environ. Sci. 2019, 75, 64-72. [CrossRef]

40. Khursheed, A.; Gaur, R.Z.; Sharma, M.K.; Tyagi, V.K.; Khan, A.A.; Kazmi, A.A. Dependence of enhanced biological nitrogen removal on carbon to nitrogen and $\mathrm{rbCOD}$ to sbCOD ratios during sewage treatment in sequencing batch reactor. J. Clean. Prod. 2018, 171, 1244-1254. [CrossRef]

41. Linares, R.V.; Li, Z.; Yangali-Quintanilla, V.; Li, Q.; Vrouwenvelder, J.S.; Amy, G.L.; Ghaffour, N. Hybrid SBR-FO system for wastewater treatment and reuse: Operation, fouling and cleaning. Desalination 2016, 393, 31-38. [CrossRef]

42. Wang, Z.; Gao, M.; Wang, Z.; She, Z.; Chang, Q.; Sun, C.; Zhang, J.; Ren, Y.; Yang, N. Effect of salinity on extracellular polymeric substances of activated sludge from an anoxic-aerobic sequencing batch reactor. Chemosphere 2013, 93, 2789-2795. [CrossRef] [PubMed]

43. Wu, S.H.; Liu, H.Y.; Yang, C.P.; Li, X.; Lin, Y.; Kai, Y.; Sun, J.T.; Teng, Q.; Du, C.; Zhong, Y.Y. High-performance porous carbon catalysts doped by iron and nitrogen for degradation of bisphenol $\mathrm{F}$ via peroxymonosulfate activation. Chem. Eng. J. 2020, 392, 123683. [CrossRef]

44. Yang, C.; Chen, H.; Zeng, G.; Yu, G.; Luo, S. Biomass accumulation and control strategies in gas biofiltration. Biotechnol. Adv. 2010, 28, 531-540. [CrossRef] [PubMed]

45. Sheng, G.P.; Yu, H.Q.; Li, X.Y. Extracellular polymeric substances (EPS) of microbial aggregates in biological wastewater treatment systems: A review. Biotechnol. Adv. 2010, 28, 882-894. [CrossRef] [PubMed]

46. Craig, J.; Klerks, P.; Heimann, K.; Waits, J. Effects of salinity, pH and temperature on the re-establishment of bioluminescence and copper or SDS toxicity in the marine dinoflagellate Pyrocystis lunula using bioluminescence as an endpoint. Environ. Pollution (Barking, Essex: 1987) 2003, 125, 267-275. [CrossRef]

47. Hu, Y.Q.; Wei, W.; Gao, M.; Zhou, Y.; Wang, G.X.; Zhang, Y. Effect of pure oxygen aeration on extracellular polymeric substances (EPS) of activated sludge treating saline wastewater. Process Saf. Environ. Prot. 2019, 123, 344-350. [CrossRef]

48. Wu, S.H.; Lin, Y.; Yang, C.; Du, C.; Teng, Q.; Ma, Y.; Zhang, D.; Nie, L.; Zhong, Y.Y. Enhanced activation of peroxymonosulfte by $\mathrm{LaFeO}_{3}$ perovskite supported on $\mathrm{Al}_{2} \mathrm{O}_{3}$ for degradation of organic pollutants. Chemosphere 2019, 237, 124478. [CrossRef]

49. Singleton, D.R.; Furlong, M.A.; Rathbun, S.L.; Whitman, W.B. Quantitative comparisons of $16 \mathrm{~S}$ rRNA gene sequence libraries from environmental samples. Appl. Environ. Microbiol. 2001, 67, 4374-4376. [CrossRef]

50. Li, H.R.; Wu, S.H.; Du, C.; Zhong, Y.Y.; Yang, C.P. Preparation, Performances, and Mechanisms of Microbial Flocculants for Wastewater Treatment. Int. J. Environ. Res. Public Health 2020, 17, 1360. [CrossRef]

51. Wu, L.; Shen, M.; Li, J.; Huang, S.; Li, Z.; Yan, Z.; Peng, Y. Cooperation between partial-nitrification, complete ammonia oxidation (comammox), and anaerobic ammonia oxidation (anammox) in sludge digestion liquid for nitrogen removal. Environ. Pollut. 2019, 254, 112965. [CrossRef] [PubMed]

52. Yi, K.; Wang, D.; Qi, Y.; Li, X.; Chen, H.; Sun, J.; An, H.; Wang, L.; Deng, Y.; Liu, J.; et al. Effect of ciprofloxacin on biological nitrogen and phosphorus removal from wastewater. Sci. Total Environ. 2017, 605-606, 368-375. [CrossRef] [PubMed]

53. Huang, W.; She, Z.; Gao, M.; Wang, Q.; Jin, C.; Zhao, Y.; Guo, L. Effect of anaerobic/aerobic duration on nitrogen removal and microbial community in a simultaneous partial nitrification and denitrification system under low salinity. Sci. Total Environ. 2019, 651, 859-870. [CrossRef] [PubMed]

54. Lebeau, T.; Braud, A.; Jezequel, K. Performance of bioaugmentation-assisted phytoextraction applied to metal contaminated soils: A review. Environ. Pollut. 2008, 153, 497-522. [CrossRef] [PubMed]

(C) 2020 by the authors. Licensee MDPI, Basel, Switzerland. This article is an open access article distributed under the terms and conditions of the Creative Commons Attribution (CC BY) license (http://creativecommons.org/licenses/by/4.0/). 